\title{
Komunikasi Marketing Web Series Melalui Digital Traveloka Web Series Marketing Communication
Through Digital Traveloka
}

\author{
Eka Prastianto ${ }^{1 *}$, Farhan Julian ${ }^{2}$, Dini Safitri ${ }^{3}$ \\ ${ }^{1}$ Program Studi Hubungan Masyarakat, Universitas Negeri Jakarta, ${ }^{2}$ Program Studi Hubungan Masyarakat, Universitas \\ Negeri Jakarta, ${ }^{3}$ Program Studi IImu Komunikasi, Universitas Negeri Jakarta
}

OPEN ACCESS

ISSN 2541-2841 (online) ISSN 2302-6790 (print)

Edited by: Nur Maghfirah Aesthetika

Reviewed by: Nikmah Suryandari

*Correspondence:

Eka Prastianto

18prastianto@gmail.com

Received: 2 Juni 2019

Accepted: 7 Juli 2019

Published: 1 September 2019

Citation:

Prastianto E, Julian F and Safitri D (2019) Komunikasi Marketing Web

Series Melalui Digital Traveloka.

Kanal. 8:1.

doi: 10.21070/kanal.v\%vi\%i.3052
In the current era of modernization, many business people have begun to develop their businesses that were previously managed offline and are directed towards online management. Web series is a recent innovation in the field of advertising with the concept of serial promotion events released by various internet media, such as through YouTube, which is the main platform for web series production. Based on the data obtained by the use of web series on Youtube media is quite a lot even some have watched more than 1 million times. The author is interested in conducting research on web series, with the aim of researching how the web series is used as a digital marketing communication strategy on Traveloka. In conducting this research the writer uses descriptive qualitative research methods. The theory in this research is content marketing in web series, in building an awareness of an advertisement of a brand. The results of this study indicate that with the digital market online there are many positive sides to being closer to consumers and also faster in time, quickly promoting or introducing products to the public, the absence of market boundaries to reach all corners of the world connected to the internet, and accuracy and speed of service are the main needs of consumers in the era of globalization.

Keywords: Web Series, Marketing Communication, Youtube

Di era modernisasi saat ini banyak pelaku bisnis yang mulai mengembangkan usahannya yang sebelumnya dikelola secara offline menjadi kearah pengelolaan online. Web series merupakan sebuah inovasi terbaru dibidang periklanan dengan konsep acara promosi berseri yang dirilis berbagai media internet,seperti melalui media youtube yang menjadi platform utama bagi para produksi web series tersebut. Berdasarkan data yang didapat penggunaan web series di media Youtube sudah terbilang cukup banyak bahkan ada yang sudah ditonton lebih dari 1 juta kali. Penulis tertarik melakukan penelitian tentang web series, dengan tujuan penelitian bagaimana web series digunakan sebagai strategi komunikasi marketing digital pada Traveloka.Dalam melakukan penelitian ini penulis menggunakan metode penelitian kualitatif berdasarkan deskriptif. Teori dalam penelitian ini adalah konten marketing di dalam web series, dalam membangun sebuah awareness dari sebuah iklan dari suatu brand. Hasil penelitian ini menunjukan dengan adanya pasar online era digital banyak sisi positif yaitu dapat lebih dekat dengan konsumen dan juga lebih cepat dalam waktu, dengan cepat mempromosikan atau mem- 
perkenalkan produk kepada publik, ketidakadaan batasan pasar untuk menjangkau seluruh pelosok dunia yang terhubung dengan internet, dan ketepatan serta kecepatan layanan menjadi kebutuhan utama konsumen di era globalisasi

Keywords: Web Series, Komunikasi Marketing, Youtube

\section{PENDAHULUAN}

Di era modernisasi saat ini banyak pelaku bisnis yang mulai mengembangkan usaha nyayang sebelumnya dikelola secara offline ke arah pengelolaan online, di samping itu hal ini untuk meng hemat waktu dan biaya sekaligus untuk mempermudah konsumen dalam menikmati produkproduk yang ditawarkan oleh perusahaan.

Informasi yang diberikan secara online merupakan salah satu hal penting yang dilakukan oleh pelaku usah. Informasi tersebut memiliki makna yang besar apabila disampaikan dengan cepat dan tepat karena mampu menambah pesatnya kemajuan usaha yang melalui media online tersebut.

Dengan adanya pemikiran yang sama dikalangan pembisnis untuk melakukkan inovasi membuat perusahaan start-up yang dapat mudah di akses dan dinikmati oleh masyarakat luas. Oleh karena itu dengan peluangnya bisnis yang diserahkan oleh pelaku usaha parwisata dengan berbagai dukungan banyaknya destinasi wisata di Indonesia,dan memiliki beragam budaya yang ada membuat daya tarik sendiri untuk pelancong berbagai wisatawan mancanegara dan dosemetik.

Menurut ${ }^{[1]}$ Rusmayanto (2017) Strategi digital marketing adalah promosi produk atau merek melalui satu atau lebih bentuk media elektronik.Digital marketing ini salah satu lebih fokus pada promosi,dengan tetap mempertimbangkan strategi pemasaran yang telah ditetapkan.

Web series merupakan sebuah konsep acara berseri yang dirilis dalam media internet. Seperti hal-nya Youtube menjadi Platform utama bagi para produser web series.Format web series sebenarnya hampir mirip dengan acara yang ditayangkan di telivisi,tetapi ada perbedaan dalam konten dan platform yang ditayangkan.Web series merupakan salah satu konten media promosi bagi perusahaan.Di Indonesia,prospek web ser ies bisa dikatakan cukup bagus. Terutama dengan animo masyarakat terhadap Youtube yang cukup tinggi. Maka sah-sah saja jika dikatakan bahwa web series merupakan senjata ampuh bagi branding perusahaan untuk memamerkan dalam karya tersendiri.

Seperti dilansir dari laman www.MetroTVNews.com, web series yang bertajuk "Sore" telah disponsori oleh Tropicana Slim sebagai konten promosinya. Webseries yang telah ditonton lebih dari 1 juta kali ini hingga sekarang di $\mathrm{k}$ anal Youtube ini mengampanyekan hidup sehat tanpa gula seba gai salah satu taktik pemasaran oleh pihak sponsor.

Komunikasi pemasaran yang menyasar anak muda ini terbilang sukses mengingat generasi muda sekarang mulai jar ang menonton televisi $\mathrm{d}$ an lebih sering menonton konten hiburan lewat media digital. Pendekatan semacam ini dapat meningkatkan emotional, value, antara brand dengan target pasarnya melalui web series.

Melihat kesuksesan web series dalam mempertahankan eksistensi brand, menarik perhati an banyak brand untuk merasakan keuntungan dari web series tersebut. Salah satunya adalah brand penjualan tiket pariwisata dan hotel Traveloka. Traveloka adalah layanan jual beli tiket pesawat,hotel, kereta,dan Penyewa kendaraan pribadi. Dalam laman resminya yakni $w w w . t r$ aveloka.com ${ }^{[2]}$ Traveloka (2019) mengatakan bahwa traveloka ada lah sistem reservasi tiket yang terintegrasi langsung den gan booking system dari airline, mel alui partner atau kerjasama yang sudah di percaya. Dengan memberikan keamanan trasaksi tiket serta kemudahan pemesanan melalui sistem otomatis, tanpa harus melalui pemesanan manual. Traveloka bekerjasama dengan trave 1 agent resmi maskapai-maskapai yang sudah ter percaya untuk menerbitkan tiket melalui web resmi nya yaitu www.traveloka.com, hal ini memungkink an konsumen yang melakukan pemesanan ti ket mendapatkan pilihan penjual yang di inginkan, serta kenyamanan dan keamanan yang terjamin. 
Cara promosi yang dilakukan oleh traveloka sejauh ini antara lain, adal ah melalui media sosial, iklan di TV dan pembagian kupon diskon. Media sosia l yang digunakannya antara lain adalah facebook, twiiter, danweb series. Untuk iklan traveloka ini sudah banyak yang kita diliat di Tv. Karena visi dari Traveloka yang sangatyakin kalau langkah yang diambilnya itu pasti sepadan de ngan yang nanti didapatkan. Dengan beriklan di televisi, pasti dilihat oleh banyak orang oleh begitu banyak mansyarakat yang mengenal namadari brand Traveloka.

Promosi web series yang sudah dijajal oleh perusahaan traveloka ini dinilai sukses dengan awalnya hanya mengeluarkan 6 episode web series.Pertam a yang diperankan oleh youtuber indonesia Arif Muhammad, animo masyarakat yang semakin tinggi dengan youtube maka menimbulk an animo yang tinggi juga untuk mengakses web series traveloka, hal tersebut dapat dilihat dari jumlah viewers yang berada di kisaran 9 sampai 10 jutaan penonton. P eralihan strategi promosi dari TV ke Webseries ini sangat menarik sehingga peneliti tertarik untukmenganalisis hal tersebut. Lalu bagaimanapengguna $\mathrm{w}$ eb series sebagai media promosi digital dier a persaingan yang semakin ketat ini, dimana pe rusahaan semakin dituntut untuk mampu bersaing secara kreatif dan mampu menggirin g animo masyarakat yang beragam tersebut kedalam media beriklan yang ringan,menarik,dan mendorong tindakan pembelian produk yang ditawarkan.

Konten yang ada didalam web series lebih beragam macamnya. Tidak hanya semangat industri kreatif yang ikut meramaikan pentas web series, para marketers pun sudah banyak yang me lakukan pendekatan pasar dengan menyuguhkan branded web series yang muncul dengan ber bagai macam genre, dari komedi, drama, hingga fiksi.Berdasarkan latarbelakang di atas penelitian ini bert ujuan untuk menjelaskan mengapa web seri es digunakan sebagai komunikasi pemasaran iklan digital dan bagaimana peran YouTube sebagai media promosi iklan digital Traveloka di Indonesia.

Menurut ${ }^{[3]}$ Hamzah (2018) Web series atau juga sering dikenal sebagai episode merupakan sebuah konsep acara berseri dalam medium internet Web series kini banyak di pilih oleh beberapa brand karena kemampuannya menciptakan sharebility. Saat ini orang lebih senang dibuat menjadi captive audience dan dibuat tidak sedang menonton sebuah iklan namun lebih memperhatikan alur pada sebuah ceritanya. Hal ini disebabkan karena brand ikut terbawa alur dalam ceritanya.

Web series ini berkenaan dengan konten marketing dimana kemampuannya membangun sebuah awareness atau dengan kata lain masyarakat lebih senang mendengarkan dongeng agar ingin melihat sebuah iklan dari suatu brand tanpa paksaan. Dengan menggunakan Sharebility, kekuatan dari Web Seriesdapat dikatakan sempurna. Share ability sendiri artinya rasa tulus dari penonton untuk membagikan konten kita ke jariangan yang lebih luas. Seperti membagikan ke aplikasi media sosial lainya ke teman dekatnya, dan keluarga tentunya membuat video Web seriesyang kita buat menjadi Viral. Biasanya Web Seriesterbagi dalam beberapa episode dan berkelanjutan dan durasi tayang nya sekitar 5-15 menit. Penonton dapat mengakses web seriesmelalui internet dengan menggunakan komputer baik laptop atau desktop dan juga telepon selulernya. Umumnya web series di unggah pada situs penyedia layanan streaming seperti Youtube berdasarkan ${ }^{[4]}$ Nurfebiaraning (2017) .

Strategi pemasaran menurut ${ }^{[5]}$ Widiawati (2019) adalah pendekatan pokok yang akan digunakan oleh unit bisnis dalam mencapai sasaran yang telah di tetapkan lebih dulu, didalamnya tercantum keputusan-keputusan pokok mengenai target pasar, penempatan, bauran pemasaran, dan tingkat biaya pemasaran yang diperlukan dan memiliki tujuan untuk mempertahankan dan meningkatkan tingkat keuntungan atau laba perusahaan, mempertahankan dan meningkatkan penjualan, mencari dan membina langganan serta usaha menguasai pasar agar perusahaan tetap hidup dan berkembang.

\section{METODE PENELITIAN}

Penelitian ini menggunakan deksripstif kualitatif, peneliti meng gambarkan bagaimana web series digunakan sebagai strategi komunika si marketing digital terhadap Traveloka. Dalam penelitian ini subjek yang dipilih adalah semua pihak yang menjalankan promosi iklan Trav- 
eloka, dengan adanya peneliti mengharap kan mendapatkan penjelasan yang rinci dalam menyelesaikan masalah dalam penelitian ini.

Menurut Sugandi dan Dacosta ${ }^{[6]}$ Sugiyono (2013) mengemukakan bahwa aktivitas dalam analisis data kualitatif dilakukan secara interaktif dan Wawancara Observasi Dokumen berlangsung secara terus menerus sampai tuntas, sehingga datanya sudah jenuh. Berikut beberapa hal yang harus diperhatikan :

1. Data Reduction (Reduksi Data) Data yang diperoleh dari lapangan jumlahnya cukup banyak,untuk itu maka perlu dicatat secara teliti dan rinci. Mereduksi data berarti merangkum, memilih hal-hal pokok, memfokuskan pada hal-hal yang penting, dicari tema dan polanya. Data yang telah direduksi memberikan gambaran yang lebih jelas dan memudahkanpeneliti untuk pengumpulan data selanjutnya.

2. Data Display (penyajian Data) Penyajian data bisa dilakukan dalam bentu uraian singkat,bagan, hubungan antar kateg ori, flowchart, dan sejenisnya.Dengan mendisplaykan data, maka memudahkanuntuk memahami yang terjadi, merencanakan kerja selanjutnya berdasarkan yang telah dipahami tersebut.

3. Conclusion Drawing / Verification Kesimpulan dalam penelitian kualitatif adalah merupakantemuan baru yang sebelumnya belum pernah ada. Temuan dapat berupa deskripsi ataugambaran suatu obyek sebelumnya masih remang-remang sehingga setelah diteliti menjadi $\mathrm{j}$ elas, dapat berupa hubungan kausal, atau i nteraktif, hipotesis atau teori.

\section{HASIL DAN PENELITIAN}

Perkembangan digital dalam globalisasi sangat berpengaruh perkembangan ekonomi termasuk pasar startup. Pasar startupsekarang sudah merambah ke dunia digital. Demi mendapatkan efesiensi dan juga khalayak yang efektif membuat banyak perusahaan berbasis online hadir dan membuat banyak manajer dari perusahan tersebut berbondong - bondong mencari jalan bisnisnya masing - masing. Seperti yang dilakukan Traveloka, agen tiket pesawat dan tiket pinginepan terbesar di Indonesia ini mempromosikan perusahaannya dengan sasaran anak muda milenial. Mereka percaya bahwa anak milenial memiliki daya beli yang besar dan memiliki jiwa konsumtif yang besar, maka dari itu Traveloka membuat suatu iklan berbasis media yang bernama Web series. Web series ditujukan untuk anak milenial yang lebih suka cerita fiktif yang mengasah imajinasinya. Traveloka membuat iklan web series ini dengan sasaran media streaming yaitu Youtube.

Berikut alasan beberapa orang tertarik dengan ajakan promosi iklan Web series menurut informan dan telah menggunakan Traveloka dalam waktu yang sering, Andika:

1. Iklan. Semua iklan yang hadir dengan menggunakan web series dapat dilihat sebagai suatu kelebihan. Iklan seperti ini dapat menarik perhatian khalayak sehingga brand dari suatu perusahaan dapat lebih dekat di kenal oleh khalayak.

2. Efensiesi biaya. Jika biasanya iklan menggunakan biaya yang lebih besar, maka dengan menggunakan web series dan media youtube ini perusahaan dapat menghemat biaya pengeluaran untuk iklan dikarenakan biayanya lebih sedikit ketimbang iklan menggunakan media TV dan lainnya.

3. Nilai kehidupan. Di dalam web series informan dapat menemukan arti atau nilai - nilai kehidupan yang bagus dan berguna. Unsur nilai- nilai ini yang tidak dapat ditemukan pada jenis iklan - iklan lainnya.

4. Lebih efektif. Iklan yang menggunakan jeni web series ini lebih efektif dalam penggunaannya ketimbang jenis iklan lainnya. Efektif yang dimaksud adalah iklan dapat tersampaikan pesannya secara langsung dan cepat oleh khalayak karena banyak khalayak yang lebih menyerap alur cerita yang di buat sehingga dapat memungkinkan khalayak mengenal iklan Traveloka ini dari ceritanya.

5. Harga Stabil. Harga yang ditawarkan oleh Traveloka sendiri stabil, sehingga tidak adanya persaingan harga. Traveloka selaku perusahaan penjual dan penyedia tiket pesawat dan tiket 
penginapan bekerjasama dengan masing - masing perusahaan tersebut untuk menghadirkan jasa mereka melalui Traveloka dan bernegoisasi untuk mendapatkan harga terbaik.

6. Efesiensi Waktu. Jika biasanya kita memesan tiket pesawat atau hotel harus datang terlebih dahulu ke bandara atau penginepan, sekarang dengan hadirnya Traveloka membuat kedua hal tersebut lebih mudah dan cepat.

Selain itu menurut pandangan informan, Dewi dalam pengguna Traveloka selama 2 tahun menjelaskan :

1. Iklan. Dengan adaanya i klan yang hadir dalam menggunakan webseries dapat dilihat sebagai suatu nilai Plus. Iklan seperti ini dapat memanfaatkan untuk mempromosikan branding traveloka yang dapat diterima oleh masyarakat.

2. Efensiesi biaya. Untuk masalah biaya biasanya web series lebih hemat dalam media iklan-nya namun untuk proses pembuatan iklannya mungkin tetap sama sama susah dan memakan waktu yang lama.

3. Nilai kehidupan. Mungkin dari setiap penampilan dari web series cenderung lebih mengedepankan unsur - unsur kehidupan seperti beramal ataupun melakukan kebaikan sehingga pesan yang disampaikan tidak hanya mempromosikan perusahaannya tetapi juga menyampaikan pesan moral yang baik.

4. Lebih efektif. Iklan yang menggunakan web series ini dinilai lebih efektif dalam penggunaannya ketimbang jenis iklan lainnya. Iklan ini lebih simple dan lebih praktis dan unsur yang tersampaikan lebih terarah ke pengguna traveloka itu sendiri maupun target sasaran publik.

5. Harga Stabil. Harga yang ditawarkan oleh Traveloka sendiri sangat relatif, sehingga tidak adanya perbandingan harga yang terlalu jauh. Traveloka selaku perusahaan penjual dan penyedia tiket pesawat dan tiket penginapan bekerjasama dengan masing - masing perusahaan tersebut untuk menghadirkan jasa mereka melalui Traveloka dan bernegoisasi untuk mendapatkan harga terbaik.

6. Efesiensi Waktu. Dalam pengguna informan tersendiri menyebut traveloka ini sangat mudah dan tidak sulit. Biasanya,j ika kita memesan tiket pesawat atau hotel harus datang terlebih dahulu ke bandara atau penginapan, sekarang dengan hadirnya Traveloka membuat kedua hal tersebut lebih mudah,cepat dan efektif wakt u dan dapat mengerjakan hal lainnya sehingga proses pemesanan dapat dilakukan di rumah.

Sedangkan menurut informan pengguna traveloka dalam $1 \frac{1}{2}$ tahun, Agus :

1. Iklan. Dengan hadirnya iklan dalam menggunakan webseries sangat efektif,karena mudah tertarik perhatian dalam masyarakat menggunakan traveloka.Sehingga Iklan ini dapat dikenal dalam branding perusahaan traveloka terhadap pelanggan.

2. Efisiensi biaya. Biasanya iklan ini membutuh biaya yang sangat besar.Namun dengan bantuan web series yang mempermudahkan dalam biaya dengan hemat.Sehingga web series ini bisa berkerjasama dengan media sosial seperti youtube,twitter,Facebook dan Lain-Lain.

3. Nilai kehidupan. Menurut agus dapat memiliki tujuan nilai kehidupan tujuan sehari-hari yang baik. Dan sampai sek arang webseries memiliki unsur dengan baik tanpa unsur yang memiliki nilai negative.

4. Lebih efektif. Iklan yang memakai web series ini dinilai lebih efektif dalam penggunaannya ketimbang jenis iklan lainnya. Efektif yang dimaksud adalah iklan dapat tersampaikan pesannya secara langsung dan cepat diterima oleh khalayak karena banyak khalayak yang lebih menyerap alur cerita yang di buat sehingga dapat memungkinkan khalayak mengenal iklan Traveloka ini dari ceritanya.l

5. Harga Stabil. Harga yang ditawarkan oleh Traveloka sendiri sangat relatif, sehingga tidak adanya persaingan harga. Traveloka selaku perusahaan penjual dan penyedia tiket pesawat dan tiket penginapan bekerjasama dengan masing - masing perusahaan tersebut untuk menghadirkan jasa mereka melalui Traveloka dan bernegoisasi untuk mendapatkan harga terbaik.

6. Efesiensi Waktu. Dalam pengguna informan tersendiri traveloka ini sangat mudah dan tidak sulit. Biasanya,jika kita memesan tiket pesawat atau hotel harus datang terlebih dahulu ke 
bandara atau penginapan, sekarang dengan hadirnya Traveloka membuat kedua hal tersebut lebih mudah,cepat dan efektif waktu.

TABLE 1 | Tabel perbandingan dari 3 informan tentang web series

\begin{tabular}{|c|c|c|c|}
\hline Nama & Andika (Mahasiswa, 20 tahun ) & $\begin{array}{l}\text { Dewi ( lbu rumah tangga, } 50 \\
\text { tahun ) }\end{array}$ & Agus ( fotographer, 38 tahun ) \\
\hline Biaya & $\begin{array}{l}\text { Biaya yang digunakan untuk } \\
\text { web series lebih kecil } \\
\text { ketimbang menggunakan jasa } \\
\text { iklan di media Tv dan lainnya }\end{array}$ & $\begin{array}{l}\text { Memang lebih sedikit murah } \\
\text { untuk biaya tapi iklannya } \\
\text { mungkin kurang ditonton orang } \\
\text { kalo di media Youtube }\end{array}$ & $\begin{array}{l}\text { Biaya yang digunakan lebih hemat dan } \\
\text { web series bisa bekerjasama dengan } \\
\text { media lainnya tidak hanya Youtube }\end{array}$ \\
\hline Waktu & $\begin{array}{l}\text { Untuk mesen tiket pesawat } \\
\text { atau hotel biasanya lebih cepat } \\
\text { dan lebih mudah }\end{array}$ & $\begin{array}{l}\text { Penggunaannya mudah dan } \\
\text { tidak sulit sehingga waktu yang } \\
\text { digunakan lebih praktis dan } \\
\text { bisa dilakukan di rumah }\end{array}$ & $\begin{array}{l}\text { Lebih mudah dan lebih cepat untuk segala } \\
\text { proses pemesanan tiket sehingga tidak } \\
\text { antre dan tidak memakan waktu yang } \\
\text { banyak }\end{array}$ \\
\hline Iklan & $\begin{array}{l}\text { Web series sebagai salah satu } \\
\text { media iklan alternative yang } \\
\text { sangat bermanfaat }\end{array}$ & $\begin{array}{l}\text { Melihat web series sebagai nilai } \\
\text { Plus dan iklan seperti ini dapat } \\
\text { memanfaatkan untuk promosi } \\
\text { branding Traveloka }\end{array}$ & $\begin{array}{l}\text { Ikaln ini menarik dan mudah menarik } \\
\text { perhatian publik yang menggunakan } \\
\text { Traveloka dan yang tidak sehingga iklan } \\
\text { dapat dikenal oleh semua kalangan }\end{array}$ \\
\hline
\end{tabular}

Dengan adanya pasar online era digital banyak sisi positif yaitu dapat lebih dekat dengan konsumen dan juga lebih cepat dalam waktu, dengan cepat mempromosikan atau memperkenalkan produk kepada publik, ketidakadaan batasan pasar untuk menjangkau seluruh pelosok dunia yang terhubung dengan internet, dan ketepatan serta kecepatan layanan menjadi kebutuhan utama konsumen di era globalisasi. Di era digital, pebisnis harus memiliki kemitraan dan memilikit kedekatan dengan era digital sebagai reformasi bisnis.

\section{KESIMPULAN}

Simpulan dalam penggunaan web series sebagai media komunikasi marketing iklan digital di Indonesia yang berfokus padastudi kasus adalah optimalisasi media sosialsebagai med ia komunikasi Pemasaran digital Traveloka seb agai aplikasi layanan pendukung traveli ng di Indonesia ternyata sangat membant $u$ dalam menciptakan, membangun, dan me mpertahankan hubungannya dengan khalayak. Segala hal negatif pun dapat dicegah dengan upaya in teraktif dan informatif melalui wadah media s osial. Sehingga citra Traveloka sendiri dapa t merubah perspektif masyarakat Indonesia terh adap aktifitas pemasaran sebuah merek Aplikasi perjalanan $\mathrm{s}$ ecara keseluruhan maupun dalam wadah digital saja.

\section{UCAPAN TERIMA KASIH}

Terimakasih pada teman-teman seperjuangan di Universitas Negeri Jakarta.

\section{REFERENCES}

Hamzah, R. E. (2018). Web Series Sebagai Komunikas Pemasaran Digital Traveloka. Jurnal Pustaka Komunikasi $1,361-374$.

Nurfebiaraning, S. (2017). Manajemen Periklanan (Yogyakarta: CV Budi Utama).

Rusmayanto (2017). Modul Pratikum Manajemen Pemasaran Berbasis IT (Jakarta: STTNF).

Sugiyono (2013). Metode Penelitian Manajemen (Bandung: CV Alfabeta).

Traveloka, A. (2019). Traveloka. http://www.traveloka.com/ 2019. (Accessed on 26 Juli 2019).

Widiawati, K. (2019). Strategi Komunikasi Pemasaran Hotel Bintang Empat Meraih Pelanggan. Jurnal Administrasi Kantor 7, 63-74.
Conflict of Interest Statement: The authors declare that the research was conducted in the absence of any commercial or financial relationships that could be construed as a potential conflict of interest.

Copyright (c) 2019 Prastianto, Julian and Safitri. This is an openaccess article distributed under the terms of the Creative Commons Attribution License (CC BY). The use, distribution or reproduction in other forums is permitted, provided the original author(s) and the copyright owner(s) are credited and that the original publication in this journal is cited, in accordance with accepted academic practice. No use, distribution or reproduction is permitted which does not comply with these terms. 